\title{
The Effect of Surveillance Cameras on Crime: Evidence from the Stockholm Subway
}

\author{
Mikael Priks
}

CESIFO WORKING PAPER NO. 2905

CAtegory 1: Public Finance

DECEMBER 2009

\footnotetext{
An electronic version of the paper may be downloaded

- from the SSRN website: Www.SSRN.com

- from the RePEc website: $\quad$ www.RePEc.org

- from the CESifo website: $\quad$ www.CESifo-group.org/wp
} 


\title{
The Effect of Surveillance Cameras on Crime: Evidence from the Stockholm Subway
}

\begin{abstract}
This paper studies the effect of surveillance cameras on crime in the Stockholm subway. Beginning in 2006, surveillance cameras were installed in the subway stations at different points in time. Difference-in-difference analysis reveals that the introduction of the cameras reduced crime by approximately 20 percent in busy stations. I also show that some of the crimes were displaced to the surrounding area.
\end{abstract}

JEL-Code: K40, J01.

Keywords: surveillance cameras, crime, natural experiments.

\author{
Mikael Priks \\ Department of Economics \\ Stockholm University \\ 10691 Stockholm \\ Sweden \\ mikael.priks@ne.su.se
}

I thank Per Pettersson-Lidbom, Jakob Svensson, David Strömberg, Martin Olsson, Anders Åkerman, Peter Egger and seminar participants at the Research Institute of Industrial Economics for helpful comments. 


\section{Introduction}

Surveillance cameras have become a common method to combat crime. Only in the UK, an estimated four million cameras have been installed (The Associated Press 2007). However, there is a major concern regarding their intrusion upon privacy. To motivate the use of surveillance cameras, it is therefore important to first carefully study the extent to which cameras deter crime.

This paper studies the introduction of surveillance cameras in the Stockholm subway. In the period 2006 to 2008 cameras were installed in 84 subway stations in Stockholm. I find that in the stations in the city (high-crime station) surveillance cameras reduced the overall crime rate by approximately 20 percent. Such a station experienced approximately 12 crimes per month before the introduction of cameras. The reduction therefore amounts to approximately two fewer crimes per station and month. As may be expected, I find that planned crime, such as pick pocketing, drug-related crime and robbery were reduced to a large extent (20 to 40 percent). Crimes committed in the heat of the moment, such as assaults, were not affected by the cameras.

The analysis also shows that cameras did not deter crime outside the city. There are at least two reasons for why the cameras work so efficiently in the stations in the city but not outside the city. Employees of the company running the subways take phone calls from the public and can use the cameras in real time to command police officers and guards to the crime scenes. According to the police, these guards reach the large stations in the city much faster compared to the stations outside the city. Criminals should therefore fear the cameras in the city more. Moreover, it is plausible that organized pick pocketing gangs and drug dealers prey in stations in the city where there are many victims. These criminals, who may well be professionals, can be expected to be particularly sensitive to the use of surveillance cameras.

I also have access to data on crime just outside the subway stations. The results indicate that a displacement effect from inside the stations where cameras are used to outside the stations where they are not used may be at work.

I am not aware of any previous work on surveillance cameras and crime in the 
economics literature. But the paper is closely related to a recent literature, which addresses the causal relationship between policing and crime. Levitt (1997) uses gubernal elections as an instrument for policing and finds that policing tends to reduce crime. ${ }^{1}$ Using natural experiments, Di Tella and Schargrodsky (2004) and Klick and Tabarrok $(2005)^{2}$ show that policing tends to reduce in particular auto theft, and Poutvaara and Priks (2009) show the police intelligence units reduce hooligan violence.

There exists a relatively large criminology literature and a number of British government reports that study how surveillance cameras affect street crime, burglary and auto theft (see Welsh and Farrington 2002 and 2008 for detailed reviews). However, this literature typically suffers either from the fact that the installation of surveillance cameras was endogenous to previous crime ${ }^{3}$, or that several types of policing were adopted at the same time, or both. In this paper, I use placebo treatments in the months before the cameras were installed and find no evidence of an increase or a reduction in crime prior to the installation of cameras. In addition, the introduction of surveillance cameras was the only policy intervention that took place during the time span studied.

Criminals roaming in subways in other countries than in Sweden are probably affected in similar ways by the presence of surveillance cameras. The results may therefore indicate how effective cameras are in other countries as well.

The outline is the following. Section 2 describes the data and the empirical strategy. The results are shown in Section 3. Section 4 analyses displacement effects and Section 5 provides a discussion.

\footnotetext{
${ }^{1}$ However, McCrary (2002) shows that after adjusting for a computational error (see also Levitt's reply, 2002) the results are not statistically significant.

${ }^{2}$ Klick and Tabarrok (2005) make use of the fact that elevated terror-alert levels in Washington led to a number of precautions made by the government, in particular an approximately 50-percent increase in street police, but also to an activation of the closed-circuit camera system that covers sensitive areas of their treatment group, the national mall. The isolated effect of the cameras can however not be analyzed.

${ }^{3}$ For example, if surveillance cameras are installed due to an increased level of crime, then individuals potentially subjects to crime may change their behavior due to the elevated crime level rather than to the cameras.
} 


\section{Data}

The dates of installation of the cameras are obtained from Storstockholms Lokaltrafik (SL). SL is owned by the Stockholm county council. It operates parts of the public transport system in the Stockholm County and is responsible for selling the rights for private firms to operate other parts of the system (such as the subway system). Beginning in the end of 2006 and during 2007 and 2008, SL installed surveillance cameras in the subway stations. According to the employees in charge of this operation, the introduction of cameras was not followed by any particular increase in the level of crime. It was instead introduced to increase the feeling of safety for the travellers. I use data from January 2005 to September 2008. In this period, surveillance cameras were installed in 84 stations. According to Swedish law, the use of surveillance cameras must be indicated by clear signs. The signs are displayed at the entrances of the subway stations as well as on the platforms next to the signs indicating the direction of the trains.

SL operates a call center where passengers and the public can call and inform about ongoing crime. This office, which was in place already before the introduction of the cameras, is manned by three officers at all times. Following a phone call, the officers can use the cameras in real time to command guards to the crime scenes.

Figure 1 depicts a map of the Stockholm subway system. Like in many other cities, it is characterized by some very large stations in the city, where several lines pass through and many much smaller stations in the suburbs where only one line passes through. All three lines pass through the central station, T-Centralen, which is by far the largest station. 


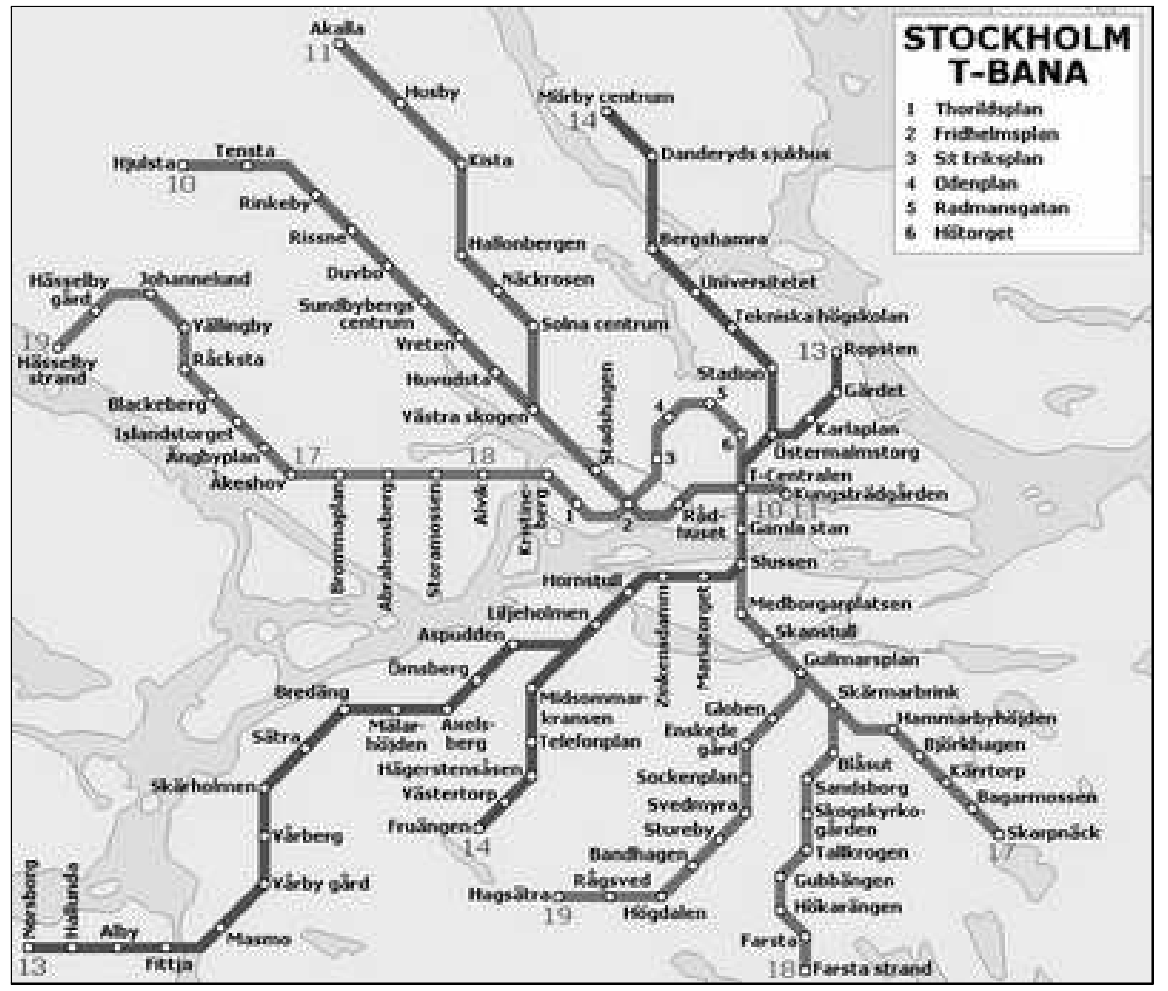

Figure 1. The Stockholm subway system

Figure 2 illustrates the distribution of the timing of introduction of the cameras. It shows that surveillance cameras tended to be installed somewhat earlier in the city compared to outside the city. On the other hand, the largest station T-Centralen was not among the early stations to install cameras and the third largest station in terms of number of passengers, Fridhemsplan, had cameras installed as late as in January 2008. 


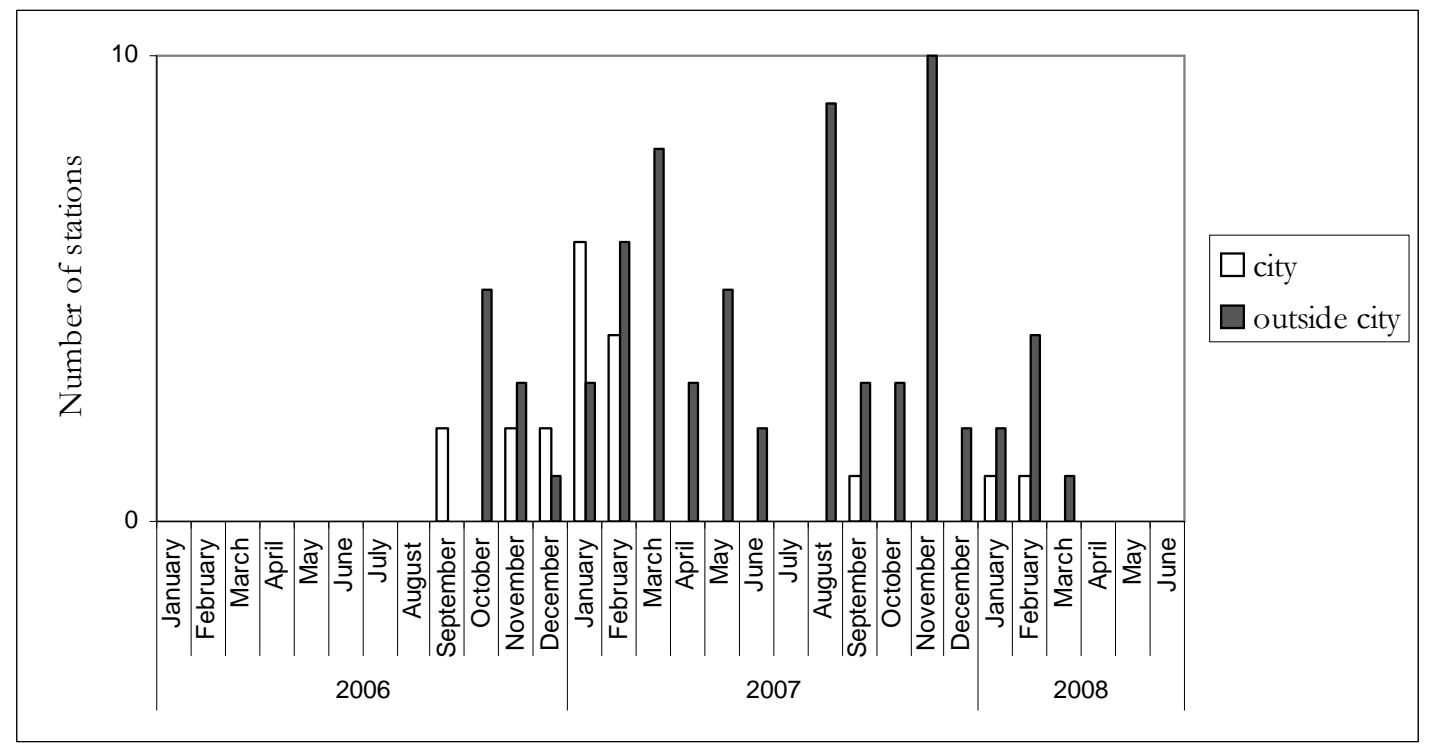

Figure 2. The timing of installation of surveillance cameras.

Table 1 shows the summary statistics for crime and the number of passengers boarding subway trains per station and day. Data on the number of boarding passengers is collected by SL. ${ }^{4}$ Data on crime is obtained from the Swedish National Police Force. It contains all crimes in the time period studied, which are filed using words related to "subway station". The first four rows show the data on the level of the station. The number of crimes per day and station before the introduction of cameras was 0.39 in the city and 0.08 outside the city. This includes all types of crimes (pick pocketing, drug related crimes, assaults, and robbery, etc.). The summary statistics indicate that crime went down in the city by approximately 20 percent after the introduction of the cameras, whereas outside the city there was almost no change at all. The number of boarding passengers varies to a large extent depending on if the stations are located in the city or outside the city. In the city, the average number of passengers per day and station in the time period studied was 32080. In the rest of the subway system, the average number of passengers per day and station was 5714. As cameras affect each and every passenger, I will as a dependent variable use crime per station divided by the average number of passengers per station. The last four rows in Table 1 shows the summary statistics for this variable. While camera does not seem to affect crime per

\footnotetext{
${ }^{4} \mathrm{SL}$ uses an automatic system with sensors on the trains that record the number of passengers boarding the trains.
} 
passenger outside the city, there are 25 percent fewer crimes per passenger in stations in the city with cameras compared to stations without cameras. To study the effects of surveillance cameras on crime, I will therefore focus on stations in the city and other stations separately.

Table 1. Summary Statistics

\begin{tabular}{lccccc}
\hline \hline & Mean & St. Dev. & Min & Max & Number of obs. \\
\hline Crime if city $=1$ and camera $=0$ & 0.39 & 1.16 & 0 & 29 & 15526 \\
Crime if city=1 and camera $=1$ & 0.3 & 0.97 & 0 & 18 & 10485 \\
Crime if city=0 and camera $=0$ & 0.08 & 0.4 & 0 & 14 & 77566 \\
Crime if city=0 and camera=1 & 0.09 & 0.46 & 0 & 15 & 33323 \\
Passengers & 10723 & 18614 & 1000 & 161138 & 136900 \\
Passengers if city=1 & 32080 & 34575 & 6472 & 161138 & 26011 \\
Passengers if city=0 & 5714 & 3913 & 1000 & 24153 & 110889 \\
Crime per passenger* if city $=1$ and camera=0 & 0.11 & 0.46 & 0 & 28 & 15526 \\
Crime per passenger if city $=1$ and camera $=1$ & 0.09 & 0.39 & 0 & 11 & 10485 \\
Crime per passenger if city $=0$ and camera $=0$ & 0.16 & 0.98 & 0 & 45 & 77566 \\
Crime per passenger if city $=0$ and camera $=1$ & 0.16 & 1.02 & 0 & 50 & 33323 \\
\hline
\end{tabular}

The unit of interest is days for crime and years for passengers. ${ }^{*}$ Crime per passenger is multiplied by 10000 .

Figure 4 depicts the changes in crime per station and passenger (multiplied by 10 000) after the cameras were introduced compared to before. 16 out of 20 stations experienced reductions in crime, three stations experienced increased crime and one station was not affected at all. While the relative changes in the three stations that experienced a positive effect is large, the absolute changes are relatively small. ${ }^{5}$ The largest station by far is T-centralen followed by Slussen and Fridhemsplan. These stations all experienced reductions larger than 20 percent. ${ }^{6}$

\footnotetext{
${ }^{5}$ The increase in the crime rate in the station Mariatorget can be explained by the fact that housings for homeless were opened in that neighborhood at the time of the introduction of cameras.

${ }^{6}$ The pattern is very similar if crime per station instead is used as dependent variable.
} 


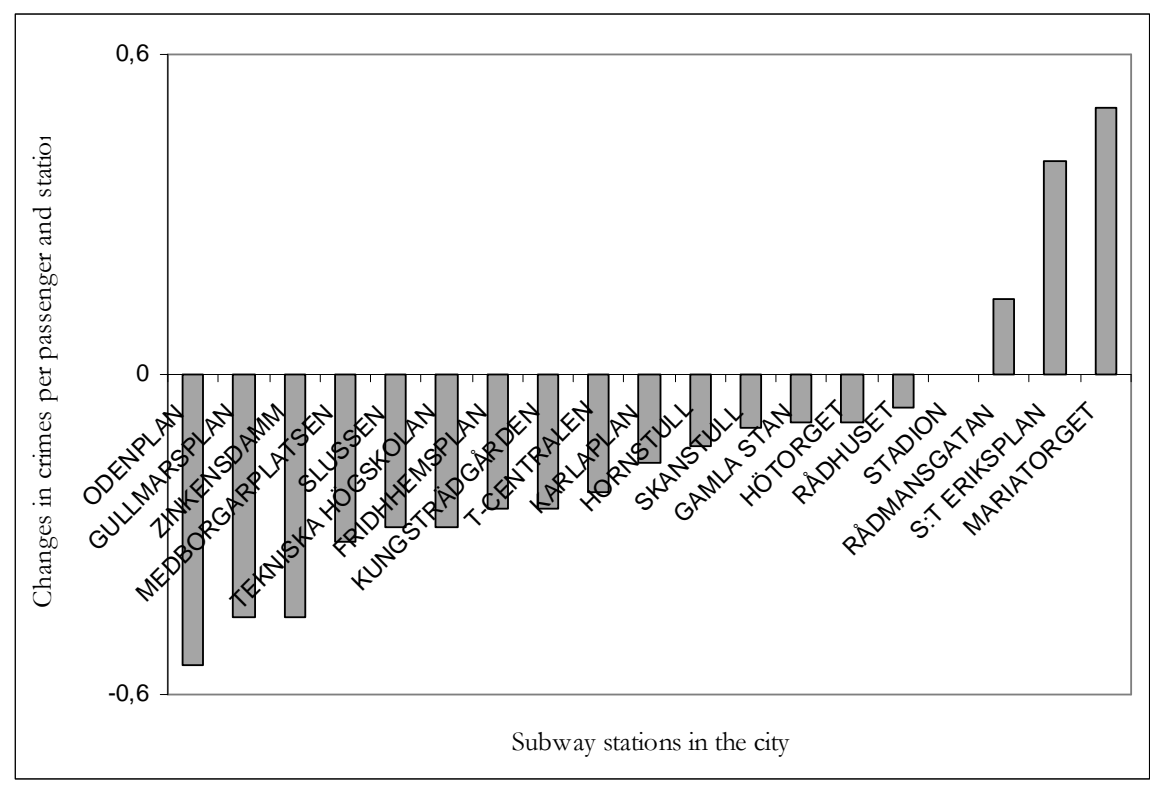

Figure 3. Changes in crimes in the city when surveillance cameras were introduced.

Figure 4 shows the overall level of crime in the subway month by month. According to statistics from SL, there are 10 percent fewer passengers than average in June, 35 percent fewer passengers in July, and 15 percent fewer passengers in August. The figure shows a clear pattern that crime follows these fluctuations where the crime level is particularly low during the summers and in particular in July. There is no clear upward or downward trend in the data.

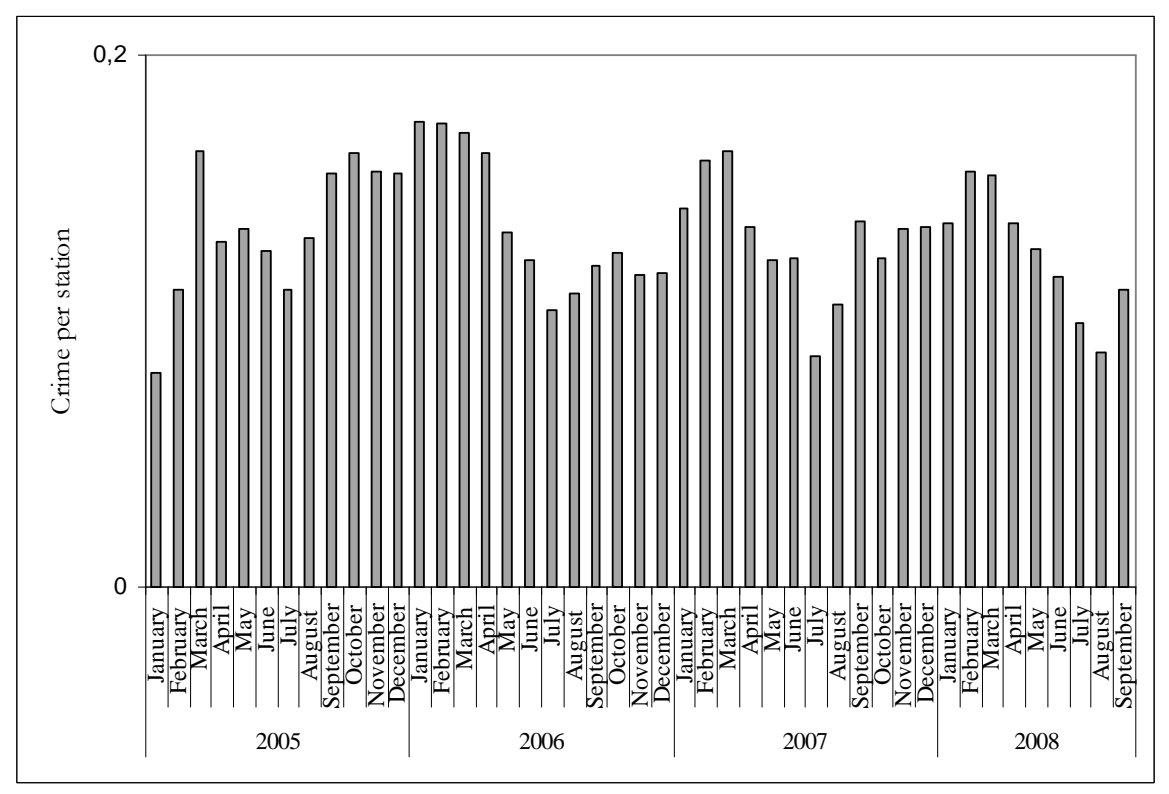

Figure 4. Crime in the subway. 
Let $Y i j$ denote the number reported crimes per passenger in station $i$ in period $j$. I will first use days as the unit of interest. I then collapse the data set by month as a robustness test. I will run the regression

$$
Y_{i j}=\alpha_{i}+\text { Bcamera }_{i j}+\gamma \text { Camera }_{i j} * \text { city }_{i}+\theta_{j}+v_{i j}
$$

where $\alpha_{i}$ is a station fixed effect. The parameter $\beta$ measures the effect of having cameras on crime outside the 20 stations in the city. $\beta+\gamma$ measures the effect in the city. The parameter $\theta_{j}$ denotes time (year, month and day) specific fixed effects in period $j$. I use OLS specifications. In some specifications, I weight the observations by the number of passengers per station.

\section{Results}

Table 2 reports the main results. Column 1 shows that there is no general significant effect of surveillance cameras on crime. I will instead focus on the stations in the city and outside the city separately. Column 2 shows the results for this specification using only station fixed effects. The estimated effect is that stations in the city with cameras had approximately 0.02 fewer incidents per passenger (multiplied by 10 000) than stations without cameras. In Column 3, year-, month- and day-fixed effects are added, which does not affect the results. In Column 4, the observations are weighted by the number of passengers at the various stations. It is striking that the coefficient is very similar independent of specification. The F-test of the joint significance of the variable Camera and the interaction variable Camera*City shows that the result is highly significant in all specifications. The camera dummy is however insignificant showing that the effect is solely at work in the city. 
TABLE 2. SURVEILLANCE CAMERAS AND CRIME IN THE SUBWAY

\begin{tabular}{lcccc}
\hline Dependent variable: crime/passenger & \multicolumn{5}{l}{} \\
\hline Sample & {$[1]$} & {$[2]$} & {$[3]$} & {$[4]$} \\
\hline Camera*City & & $-0.031^{* * *}$ & $-0.031^{* * *}$ & $-0.033^{* * *}$ \\
& $(0.012)$ & $(0.011)$ & $(0.009)$ \\
Camera & -0.007 & 0.014 & 0.004 & 0.013 \\
& $(0.007)$ & $(0.009)$ & $(0.011)$ & $(0.008)$ \\
Year, month and day fixed effects & Yes & No & Yes & Yes \\
Obervations weighted by passengers & Yes & No & No & Yes \\
Constant & $0.155^{* * *}$ & $0.148^{* * *}$ & $0.158^{* * *}$ & $0.155^{* * *}$ \\
& $(0.012)$ & $(0.002)$ & $(0.016)$ & $(0.016)$ \\
$\mathrm{R}^{2}$ & 0.01 & 0.01 & 0.01 & 0.01 \\
F-test of joint significance of Camera and & \multicolumn{5}{c}{5.28} & 5.63 & 7.95 \\
Camera*City (p-value within paranthesis) & 136900 & $(0.024)$ & $(0.020)$ & $(0.006)$ \\
Observations & 136900 & 136900 & 136900 \\
\hline Note: ${ }^{* * *}$ indicates signficance at the 1 percent level, ** at the 5 percent level, and & &
\end{tabular}

Since the average number of crimes per day and passenger (multiplied by 10000) before the introduction of cameras was 0.11 , the estimated effect amounts to approximately a 20 percent reduction in crime in the city. An average station in the city has approximately 30000 passengers per day. Therefore, the introduction of surveillance cameras leads to 24 fewer crimes per station and year.

A concern with these OLS regressions is that because of potential serial correlation, they may underestimate the standard errors. As a robustness test, I collapse the whole data set for each station into monthly data. As shown in Table 3, the results are very similar with this specification. 


\begin{tabular}{lccc}
\hline Dependent variable: crime/passenger & & & \\
\hline Sample & {$[1]$} & {$[2]$} & {$[3]$} \\
\hline Camera*City & $-0.031^{* * *}$ & $-0.032^{* * *}$ & $-0.033^{* * *}$ \\
& $(0.012)$ & $(0.012)$ & $(0.009)$ \\
Camera & 0.014 & 0.005 & 0.014 \\
& $(0.012)$ & $(0.012)$ & $(0.009)$ \\
Year, month and day fixed effects & No & Yes & Yes \\
Obervations weighted by passengers & No & No & Yes \\
Constant & $0.148^{* * *}$ & $0.131^{* * *}$ & $0.126^{* * *}$ \\
& $(0.002)$ & $(0.010)$ & $(0.006)$ \\
F-test of joint significance of Camera and & 5.14 & 5.10 & 6.64 \\
Camera*City (p-value within paranthesis) & $(0.026)$ & $(0.026)$ & $(0.011)$ \\
$\mathrm{R}^{2}$ & 0.15 & 0.16 & 0.22 \\
Observations & 4500 & 4500 & 4500 \\
\hline Note: $* * *$ indicates signficance at the 1 percent level, $* *$ at the 5 percent level, and & \\
$*$ at the 10 percent level. The regressions include station-fixed effects and & & \\
the standard errors are clustered at the level of the stations. & & &
\end{tabular}

The most common types of crime in the subway are pickpocketing, drug-related crime and assaults. We may expect that planned crimes are deterred by cameras whereas crimes that are committed in the heat of the moment may not be deterred. Indeed, Table 4 shows that pickpocketing, drug-related crimes as well as robbery, which all tend to be planned, are significantly reduced in the city when surveillance cameras were introduced. Column 1 shows that pickpocketing was reduced by approximately 20 percent compared to the average, 0,017. Column 2 shows that when weighting the observations by the number of passengers, the introduction of cameras in subway stations outside the city in fact leads to more pickpocketing in these stations. As argued above, it make sense that surveillance cameras are more efficient in the stations in the city, in particular when pickpocketing is considered. This result could therefore be due to a displacement of crime from stations in the city with cameras to stations outside the city with cameras. Column 3 and 4 show that drug-related crime was reduced by 40 percent compared to the average 0,014 and column 5 and 6 show that robbery was reduced by over 100 percent compared to the average $0,0004 .{ }^{7}$ However, since robbery is rare and since the result is only marginally significant, we should be cautious with

\footnotetext{
${ }^{7}$ The results remain almost identical when collapsing the data to monthly data.
} 
the interpretation of this result. As expected, assaults, which do not tend to be very planned, are not affected by surveillance cameras.

TABLE 4. SURVEILLANCE CAMERAS, PICKPOCKETING DRUG-RELATED CRIME AND ROBBERY IN THE SUBWAY

Dependent: variable column [1] and [2] pickpocketing/passenger, and column [3] and [4] drug-related crime/passenger, and [5] and [6] robbery/passenger.

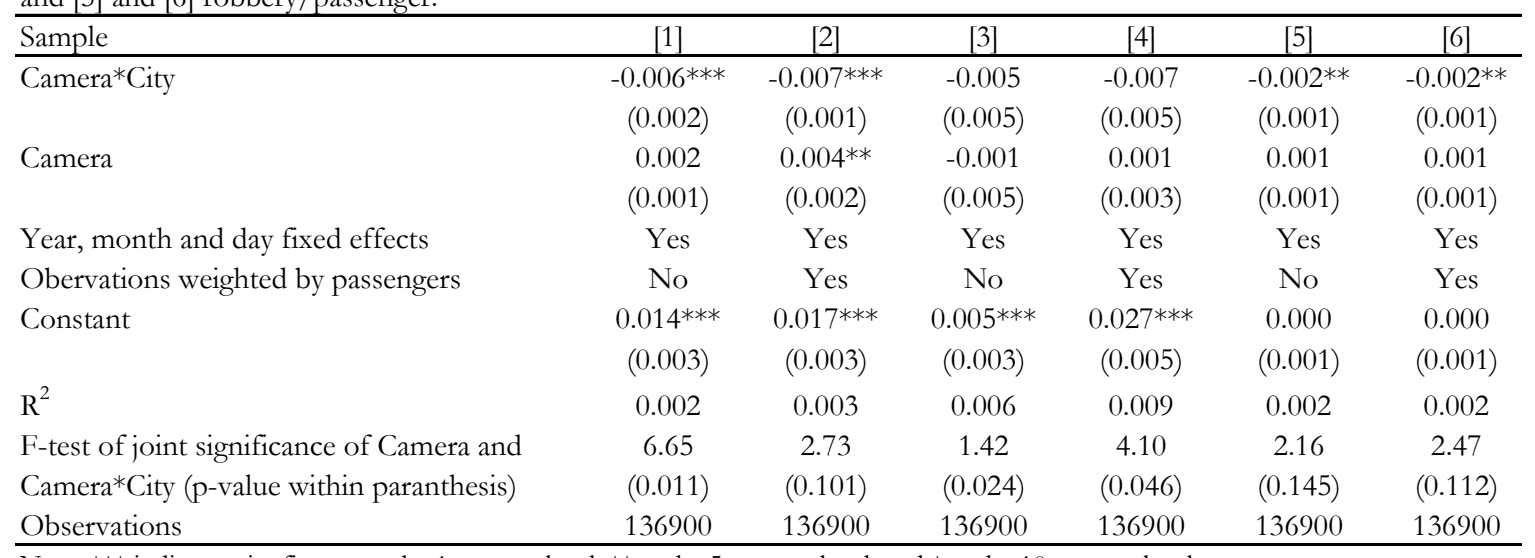

Note: *** indicates signficance at the 1 percent level, ${ }^{* *}$ at the 5 percent level, and ${ }^{*}$ at the 10 percent level.

The regressions include station-fixed effects and the standard errors are clustered at the level of the stations.

As a placebo treatment, I study difference-in-difference estimates for the time periods before the introduction of the surveillance cameras. Table 5 shows that there is no significant increase or decrease in crime in the 3-month and 12-month period before the introduction of cameras, neither in the city nor outside the city. This shows that the installation of cameras was exogenous to previous crime. 


\begin{tabular}{|c|c|c|c|c|}
\hline \multicolumn{5}{|l|}{ Dependent variable: crime/passenger } \\
\hline Sample & [1] & [2] & [3] & [4] \\
\hline \multirow[t]{2}{*}{ Placebo 3 months * city } & & -0.022 & & \\
\hline & & $(0.017)$ & & \\
\hline \multirow[t]{2}{*}{ Placebo 3 months } & 0.005 & 0.003 & & \\
\hline & $(0.012)$ & $(0.014)$ & & \\
\hline \multirow[t]{2}{*}{ Placebo 12 months } & & & -0.039 & -0.005 \\
\hline & & & $(0.012)$ & $(0.013)$ \\
\hline \multirow[t]{2}{*}{ Placebo 12 months * city } & & & & -0.003 \\
\hline & & & & $(0.011)$ \\
\hline \multirow[t]{2}{*}{ Camera * City } & & $-0.030 * *$ & & $-0.030 * *$ \\
\hline & & $(0.013)$ & & $(0.034)$ \\
\hline \multirow{2}{*}{ Camera } & -0.004 & 0.002 & -0.010 & -0.004 \\
\hline & $(0.012)$ & $(0.012)$ & $(0.020)$ & $(0.021)$ \\
\hline \multirow[t]{2}{*}{ Constant } & $0.139 * * *$ & $0.138^{* * *}$ & $0.138^{* * *}$ & $0.138 * * *$ \\
\hline & $(0.010)$ & $(0.010)$ & $(0.010)$ & $(0.0010)$ \\
\hline F-test of joint significance of Placebo 3 months and & & 1.61 & & \\
\hline Placebo 3 months*City (p-value within paranthesis) & & $(0.21)$ & & \\
\hline F-test of joint significance of Placebo 12 months and & & & & 0.38 \\
\hline Placebo 12 months*City (p-value within paranthesis) & & & & $(0.54)$ \\
\hline $\mathrm{R}^{2}$ & 0.16 & 0.16 & 0.16 & 0.16 \\
\hline Observations & 4500 & 4500 & 4500 & 4500 \\
\hline
\end{tabular}

Note: $* * *$ indicates signficance at the 1 percent level, ${ }^{* *}$ at the 5 percent level, and ${ }^{*}$ at the 10 percent level.

The regressions include station-fixed effects and the standard errors are clustered at the level of the stations.

The regressions include year and month fixed effects.

\section{Displacement Effects}

I am able to address the displacement effect by using data on crime just outside the subway stations where cameras are not aloud. I have access to data on crimes that took place in the entrée to the subway, the ticket hall, the hallway, or just outside the subway station, which includes on buss stops, parking lots or parking places for bicycles. Table 6 shows that crime outside the stations in the city was increased when cameras were introduced. The F-test shows that the result is highly significant. The reductions are also large, approximately 100 percent. However, there are very few observations in this data set (255 in the city and 267 outside the city) so we must be very cautious when interpreting the results. Nevertheless, they indicate that part of the reduction in crime inside the stations in the city is displaced to the area just outside the stations. 
TABLE 6. SURVEILLANCE CAMERAS AND CRIME OUTSIDE THE SUBWAY

\begin{tabular}{lcc}
\hline Dependent variable: crime/passenger & & \\
\hline Sample & {$[1]$} & {$[2]$} \\
\hline Camera*City & 0.001 & 0.002 \\
& $(0.001)$ & $(0.001)$ \\
Camera & 0.002 & 0.000 \\
& $(0.002)$ & $(0.001)$ \\
Year, month and day fixed effects & Yes & Yes \\
Obervations weighted by passengers & No & Yes \\
Constant & $0.014^{* * *}$ & $0.006^{* * *}$ \\
& $(0.005)$ & $(0.002)$ \\
F-test of joint significance of Camera and & 4.75 & 7.27 \\
Camera*City (p-value within paranthesis) & $(0.032)$ & $(0.008)$ \\
$\mathrm{R}^{2}$ & 0.002 & 0.002 \\
Observations & 117734 & 117734 \\
\hline Note: $* * *$ indicates signficance at the 1 percent level, ** at the 5 percent level, and & \\
$*$ at the 10 percent level. The regressions include station-fixed effects and & \\
the standard errors are clustered at the level of the stations. & &
\end{tabular}

\section{Discussion}

Firms and governments in many countries have started to use surveillance cameras in order to reduce crime. However, the potential deterrent effect of the cameras is not yet well-understood. I use a natural experiment from the Stockholm subway system and find that surveillance cameras reduce crime by approximately 20 percent in the stations in the city. They do, however, not affect crime outside the city. Why do cameras deter crime in the city only? There could be at least four reasons for this. First, according to the police, guards and police officers are located closer to the large stations. This implies that the cameras are more efficient in the large stations in the sense that they can be used by law enforcement officials to rapidly call for guards and police. In the suburbs, this process takes longer time and the criminals have more time to escape. Second, it is possible that organized criminals prey in large stations where there are many passengers. Indeed, I find large reductions in pick pocketing and drug-related crime in the crowded stations, which supports this hypothesis. Third, the large stations are typically indoor stations where the light is good and cameras may therefore be more efficient. The smaller stations in the suburbs are typically outdoor 
and criminals may feel covered by the dark. In addition, parts of those platforms are not covered by a roof and cameras can therefore not cover the whole station. Finally, since there are few crimes in stations with few passengers, the data is noisier there, and this could explain why the results are not significant.

To be able to answer the question if cameras should be used or not it is necessary to take into account the costs of the cameras. According to SL, the costs of the cameras and the surrounding equipment is 33 million crowns (approximately 3.3 million euro). SL's call center had the same number of employees (15) before and after the introduction of the cameras so these costs have not changed. I have estimated that cameras deter approximately 450 crimes per year in the subway stations. On the other hand, 125 crimes were displaced to non-surveilled areas outside the stations. Therefore, in total, assuming that there is no other displacement effect, there were 325 fewer crimes due to the cameras. Assume that there are no costs of intrusion upon privacy and that cameras needs to be changed every fifth year. Then the costs to reduce one crime is approximately 20000 crowns (approximately 2000 euro).

It is hard to estimate the value of a crime that did not take place. The individual subject to the crime of course incurs a substantial cost. More generally, reduced crime rates leads to a feeling of safety among passengers. SL annually performs surveys where passengers are asked about how satisfied they are with SL. One part of this survey asks about how safe the passengers perceive that they are. In the 2009 survey it is reported that women travelling alone during evening and nights feel 11 percent more safe in 2009 compared to in 2006 (AB SL Marknadsanalys 2009). It if of course not clear that this change is due to the introduction of cameras. Nevertheless, it may indicate the cameras increase the feeling of safety, which, after all, is the reason for why they were installed in the first place. In sum, the benefit of the surveillance cameras may be substantially higher than 20000 crowns. Since the cameras are efficient in the city only, the analysis suggests that they may be used in the city only. Cameras would then be installed in 20 (instead of 100) stations which would cut the costs dramatically. In this case, and under the assumption that crime is only displaced to areas just outside the subway 
stations, my policy conclusion is that the benefits of using cameras in subway stations in the city dominate the costs.

I believe that the results of the study can be used also outside Sweden. After all, criminals in the subways and on the streets behave similarly and should react in a similar way to the presence of surveillance cameras. Having said that, more studies using exogenous variation and isolated policy intervention would certainly help policy makers when deciding on whether cameras should be used or not.

\section{References}

[1] AB SL Marknadsanalys (2009), "Upplevd kvalitetet i SL-trafiken".

[2] Associated Press, The, May 2, 2007, "U.K. Privacy Watchdog Seeks More Powers", The New York Times.

[3] Di Tella, Rafael and Schargrodsky, Ernesto (2004), "Do Police Reduce Crime? Estimates Using the Allocation of Police Forces After a Terrorist Attack", American Economic Review, 94: 115-33.

[4] Klick, Jonathan and Tabarrok, Alexander (2005), "Using Terror Alert Levels to Estimate the Effect of Police on Crime", Journal of Law and Economics, 68: 267279.

[5] Levitt, Steven D. (1997), "Using Electoral Cycles in Police Hiring to Estimate the Effect of Police on Crime: Reply", American Economic Review, 92: 1244-50.

[6] McCrary, Justin (2002), "Using Electoral Cycles in Police Hiring to Estimate the Effect of Police on Crime: Comment", American Economic Review, 87: 1236-43.

[7] Pouvaara Panu and Priks Mikael (2009), "The Effect of Police Intelligence on Group Violence: Evidence from Reassignments in Sweden", Journal of Public Economics, 93: $403-411$. 
[8] Welsh Brandon C. and Farrington David P. (2002), "Crime Prevention Effects of Closed Curcuit Television: a Systematic Review", Home Office Research Studies, 252.

[9] Welsh, Brandon C. and Farrington, David P. (2008), "Closed-Circuit Television Surveillance and Crime Prevention - A Systematic Review", BRA, report 2007:29. 


\section{CESifo Working Paper Series}

for full list see www.cesifo-group.org/wp

(address: Poschingerstr. 5, 81679 Munich, Germany, office@cesifo.de)

2845 Guglielmo Maria Caporale, Burcu Erdogan and Vladimir Kuzin, Testing for Convergence in Stock Markets: A Non-Linear Factor Approach, November 2009

2846 Michèle Belot and Jan Fidrmuc, Anthropometry of Love - Height and Gender Asymmetries in Interethnic Marriages, November 2009

2847 Volker Nitsch and Nikolaus Wolf, Tear Down this Wall: On the Persistence of Borders in Trade, November 2009

2848 Jan K. Brueckner and Stef Proost, Carve-Outs Under Airline Antitrust Immunity, November 2009

2849 Margarita Katsimi and Vassilis Sarantides, The Impact of Fiscal Policy on Profits, November 2009

2850 Scott Alan Carson, The Relationship between Stature and Insolation: Evidence from Soldiers and Prisoners, November 2009

2851 Horst Raff and Joachim Wagner, Intra-Industry Adjustment to Import Competition: Theory and Application to the German Clothing Industry, November 2009

2852 Erkki Koskela, Impacts of Labor Taxation with Perfectly and Imperfectly Competitive Labor Markets under Flexible Outsourcing, November 2009

2853 Cletus C. Coughlin and Dennis Novy, Is the International Border Effect Larger than the Domestic Border Effect? Evidence from U.S. Trade, November 2009

2854 Johannes Becker and Clemens Fuest, Source versus Residence Based Taxation with International Mergers and Acquisitions, November 2009

2855 Andreas Hoffmann and Gunther Schnabl, A Vicious Cycle of Manias, Crashes and Asymmetric Policy Responses - An Overinvestment View, November 2009

2856 Xavier Vives, Strategic Supply Function Competition with Private Information, November 2009

2857 M. Hashem Pesaran and Paolo Zaffaroni, Optimality and Diversifiability of Mean Variance and Arbitrage Pricing Portfolios, November 2009

2858 Davide Sala, Philipp J.H. Schröder and Erdal Yalcin, Market Access through Bound Tariffs, November 2009

2859 Ben J. Heijdra and Pim Heijnen, Environmental Policy and the Macroeconomy under Shallow-Lake Dynamics, November 2009 
2860 Enrico Spolaore, National Borders, Conflict and Peace, November 2009

2861 Nina Czernich, Oliver Falck, Tobias Kretschmer and Ludger Woessmann, Broadband Infrastructure and Economic Growth, December 2009

2862 Evžen Kočenda and Martin Vojtek, Default Predictors and Credit Scoring Models for Retail Banking, December 2009

2863 Christian Gollier and Martin L. Weitzman, How Should the Distant Future be Discounted when Discount Rates are Uncertain?, December 2009

2864 Tiberiu Dragu and Mattias Polborn, Terrorism Prevention and Electoral Accountability, December 2009

2865 Torfinn Harding and Beata Smarzynska Javorcik, A Touch of Sophistication: FDI and Unit Values of Exports, December 2009

2866 Matthias Dischinger and Nadine Riedel, There's no Place like Home: The Profitability Gap between Headquarters and their Foreign Subsidiaries, December 2009

2867 Andreas Haufler and Frank Stähler, Tax Competition in a Simple Model with Heterogeneous Firms: How Larger Markets Reduce Profit Taxes, December 2009

2868 Steinar Holden, Do Choices Affect Preferences? Some Doubts and New Evidence, December 2009

2869 Alberto Asquer, On the many Ways Europeanization Matters: The Implementation of the Water Reform in Italy (1994-2006), December 2009

2870 Choudhry Tanveer Shehzad and Jakob De Haan, Financial Reform and Banking Crises, December 2009

2871 Annette Alstadsæter and Hans Henrik Sievertsen, The Consumption Value of Higher Education, December 2009

2872 Chris van Klaveren, Bernard van Praag and Henriette Maassen van den Brink, Collective Labor Supply of Native Dutch and Immigrant Households in the Netherlands, December 2009

2873 Burkhard Heer and Alfred Maußner, Computation of Business-Cycle Models with the Generalized Schur Method, December 2009

2874 Carlo Carraro, Enrica De Cian and Massimo Tavoni, Human Capital Formation and Global Warming Mitigation: Evidence from an Integrated Assessment Model, December 2009

2875 André Grimaud, Gilles Lafforgue and Bertrand Magné, Climate Change Mitigation Options and Directed Technical Change: A Decentralized Equilibrium Analysis, December 2009 
2876 Angel de la Fuente, A Mixed Splicing Procedure for Economic Time Series, December 2009

2877 Martin Schlotter, Guido Schwerdt and Ludger Woessmann, Econometric Methods for Causal Evaluation of Education Policies and Practices: A Non-Technical Guide, December 2009

2878 Mathias Dolls, Clemens Fuest and Andreas Peichl, Automatic Stabilizers and Economic Crisis: US vs. Europe, December 2009

2879 Tom Karkinsky and Nadine Riedel, Corporate Taxation and the Choice of Patent Location within Multinational Firms, December 2009

2880 Kai A. Konrad, Florian Morath and Wieland Müller, Taxation and Market Power, December 2009

2881 Marko Koethenbuerger and Michael Stimmelmayr, Corporate Taxation and Corporate Governance, December 2009

2882 Gebhard Kirchgässner, The Lost Popularity Function: Are Unemployment and Inflation no longer Relevant for the Behaviour of Germany Voters?, December 2009

2883 Marianna Belloc and Ugo Pagano, Politics-Business Interaction Paths, December 2009

2884 Wolfgang Buchholz, Richard Cornes and Dirk Rübbelke, Existence and Warr Neutrality for Matching Equilibria in a Public Good Economy: An Aggregative Game Approach, December 2009

2885 Charles A.E. Goodhart, Carolina Osorio and Dimitrios P. Tsomocos, Analysis of Monetary Policy and Financial Stability: A New Paradigm, December 2009

2886 Thomas Aronsson and Erkki Koskela, Outsourcing, Public Input Provision and Policy Cooperation, December 2009

2887 Andreas Ortmann, "The Way in which an Experiment is Conducted is Unbelievably Important": On the Experimentation Practices of Economists and Psychologists, December 2009

2888 Andreas Irmen, Population Aging and the Direction of Technical Change, December 2009

2889 Wolf-Heimo Grieben and Fuat Şener, Labor Unions, Globalization, and Mercantilism, December 2009

2890 Conny Wunsch, Optimal Use of Labor Market Policies: The Role of Job Search Assistance, December 2009

2891 Claudia Buch, Cathérine Tahmee Koch and Michael Kötter, Margins of International Banking: Is there a Productivity Pecking Order in Banking, too?, December 2009 
2892 Shafik Hebous and Alfons J. Weichenrieder, Debt Financing and Sharp Currency Depreciations: Wholly vs. Partially Owned Multinational Affiliates, December 2009

2893 Johannes Binswanger and Daniel Schunk, What is an Adequate Standard of Living during Retirement?, December 2009

2894 Armin Falk and James J. Heckman, Lab Experiments are a Major Source of Knowledge in the Social Sciences, December 2009

2895 Hartmut Egger and Daniel Etzel, The Impact of Trade on Employment, Welfare, and Income Distribution in Unionized General Oligopolistic Equilibrium, December 2009

2896 Julian Rauchdobler, Rupert Sausgruber and Jean-Robert Tyran, Voting on Thresholds for Public Goods: Experimental Evidence, December 2009

2897 Michael McBride and Stergios Skaperdas, Conflict, Settlement, and the Shadow of the Future, December 2009

2898 Ben J. Heijdra and Laurie S. M. Reijnders, Economic Growth and Longevity Risk with Adverse Selection, December 2009

2899 Johannes Becker, Taxation of Foreign Profits with Heterogeneous Multinational Firms, December 2009

2900 Douglas Gale and Piero Gottardi, Illiquidity and Under-Valuation of Firms, December 2009

2901 Donatella Gatti, Christophe Rault and Anne-Gaël Vaubourg, Unemployment and Finance: How do Financial and Labour Market Factors Interact?, December 2009

2902 Arno Riedl, Behavioral and Experimental Economics Can Inform Public Policy: Some Thoughts, December 2009

2903 Wilhelm K. Kohler and Marcel Smolka, Global Sourcing Decisions and Firm Productivity: Evidence from Spain, December 2009

2904 Marcel Gérard and Fernando M. M. Ruiz, Corporate Taxation and the Impact of Governance, Political and Economic Factors, December 2009

2905 Mikael Priks, The Effect of Surveillance Cameras on Crime: Evidence from the Stockholm Subway, December 2009 